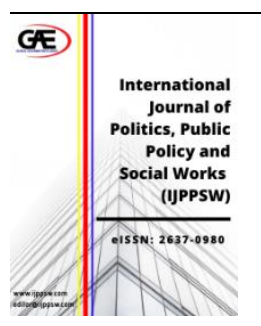

\author{
INTERNATIONAL JOURNAL OF \\ POLITICS, PUBLICS POLICY \\ AND SOCIAL WORKS \\ (IJPPSW) \\ www.ijppsw.com
}

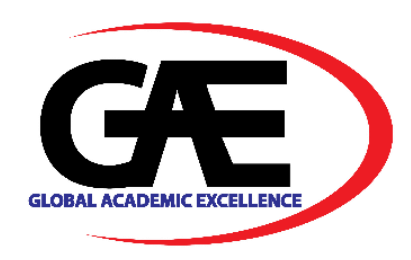

\title{
EXPLORING THE FUNDAMENTALS OF FOREIGN POLICY IN MALAYSIA: DEFINITIONS, PREMIERSHIP AND FOREIGN POLICY DECISIONS
}

\author{
Faridah Jaafar $^{1}$, Nurulhasanah Abdul Rahman ${ }^{2 *}$ \\ 1 Department of Political Science, School of Distance Education, Universiti Sains Malaysia (USM), Malaysia \\ Email: faridahjaafar@usm.my \\ 2 Department of Political Science, School of Distance Education, Universiti Sains Malaysia (USM), Malaysia \\ Email: hasanah.rahman89@yahoo.com \\ Corresponding Author
}

\section{Article Info:}

Article history:

Received date:02.09.2020

Revised date: 10.09 .2020

Accepted date: 13.09 .2020

Published date: 15.09 .2020

\section{To cite this document:}

Jaafar, F. \& Rahman, N. A. (2020). Exploring The Fundamentals Of Foreign Policy In Malaysia: Definitions, Premiership And Foreign Policy Decisions. International Journal of Politics, Publics Policy and Social Works, 2 (6), 01-15.

DOI: 10.35631/IJPPSW.26001.

\begin{abstract}
:
Academic discussion on the fundamentals of foreign policy often draws a debatable argument in International Relations research. Yet, the effort to unravel the core definition of foreign policy is limited and largely unobserved. Regardless of any foreign policy beliefs, understanding the fundamentals is crucial to make informed decisions related to international affairs. Therefore, this paper seeks to explore the fundamentals of foreign policy in twofold namely; (1) Working on outlining the definition of foreign policy and (2) Factors that influence foreign policy decisions. By employing secondary data, the systematic review was conducted based on past literature with respect to foreign policy studies and premiership; extracted from reputable databases. The literature search was limited to English sources, published in Scopus, ScienceDirect, and indexed in Google Scholar from 1960 to 2020. Accordingly, five factors emerged from the review which revealed the significant influence of individual, position, government, society, and system in formulating foreign policy decisions. These factors are considered as drivers in the foreign policy landscape and evidently shaped the Malaysian principles in collaborating with international cooperation. Finally, this paper provides insights into the existing literature with a detailed definition of foreign policy and narrates the way foreign policy decisions have effects on Malaysian political affairs. A set of recommendations were proposed as a brief agenda for future research.
\end{abstract}

\section{Keywords:}

Decision-Making, Foreign Policy, Government, Malaysia, International Relation, Malaysian Premiership, Policy Analysis 


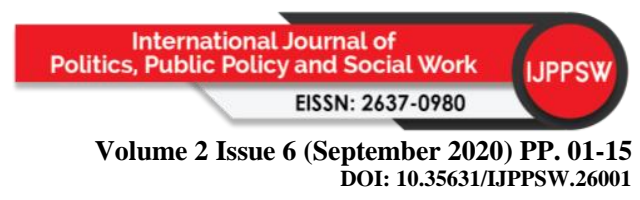

\section{Introduction}

Throughout the past years, many countries have witnessed the reign of diplomacy dispute among 'world powers' especially since the Donald Trump's presidency in United States (US). The spike of racism issues, crisis talk of free trade and immigration problems as well as response to COVID-19 pandemic in US had led to a new trend in contemporary foreign policy research (Erdogan \& Habash, 2020; Kattan, 2020; Lacatus \& Meibauer, 2020). Putting this matter into perspective, political change in US had revolutionised the foreign policy in other countries as well (Lacatus \& Meibauer, 2020; Siniver \& Featherstone, 2020).

In fact, it is becoming a domino effect which Trump's policy position in US forcing others to react accordingly. Mirroring the current situation in US as reference, the President's personal beliefs and actions are no longer separated from his individual identity but to be considered as national interests (Erdogan \& Habash, 2020; Kattan, 2020; Lacatus \& Meibauer, 2020). Hence, it has affected the whole system of international relations and jeopardise the political order (Lacatus \& Meibauer, 2020; Siniver \& Featherstone, 2020). Working upon this fact, understanding the core definitions of foreign policy and factors influencing foreign policy decisions are at utmost importance.

In a glance, foreign policy is regarded as part of International Relations and generally interpreted as purposeful action in fulfilling national interest coming from political-level decision based on individual or group considerations (As, 2018). Tracing back classical foreign policy definition to past scholars, Frankel (1963) remarked that foreign policy contains two important elements namely; decisions and actions. These elements are not limited to official documents and speeches but also integrate non-verbalized line of decisions and actions (see Haesebrouck \& Joly, 2020). Even though the term of foreign policy is ubiquitous in past literature, there is limited studies had offered clear definitions or detailed descriptions of the fundamentals of foreign policy.

Yet, Hoffman (1968) made an attempt to provide a simpler definition to represent foreign policy as: Politics in the international scene (as mentioned in Carlsnaes, 1980). The author simply justified foreign policy as any plan that government chooses to embark upon other countries while no explanation on who was involved in the politics and what kind of plans the government intended. On the other hand, Rosenau (1984) referred foreign policy as authoritative actions taken by governments or their commitment to give orders either to maintain the desirable aspects of the international environment or to amend its undesirable aspects. This time, a more detailed definition was proposed but it caused confusion to some scholars regarding what constitute desirable and undesirable aspects.

A few years later, Hermann (1990) defined foreign policy as goal-oriented or problemoriented program, being formulated by policymakers and directed towards entities outside the state's political jurisdiction. This definition provides more substance and convincing to describe the fundamentals of foreign policy which primarily must include course of action (program), policy makers, and scope of jurisdiction. In current literature, policy researchers are no longer focusing on the definition or fundamentals of foreign policy but directly discuss the respective topics such as specific foreign policy, democracy, ideology, and the application of foreign policy in particular countries, among others (Hara, 2012; Bevir \& Daddow, 2015; Efimova \& Strebkov, 2020; Sundstrom \& Elgstrom, 2020). 


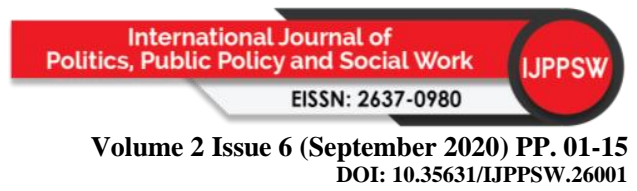

To feed the need for the current foreign policy definition, policy scholars had produced numerous definitions to fit the rapidly changing structures of the world order. Ironically, these definitions add more questions than answers which puzzled existing researchers to efficiently capture the gist of foreign policy concepts (As, 2018; Haesebrouck \& Joly, 2020). In basic understanding, foreign policy is referred as a guideline to steer interactions among nation-states. However, the implications of inaccurate description of foreign policy may risk a country to function in complete isolation (As, 2018). In fact, as mentioned earlier regarding the impact of personal preference turned into national interest; it is crucial to elucidate the factors that affect foreign policy decision-making. Therefore, taking into account the importance and complexity of foreign policy concepts, there is an urgency to outline a detailed definition of foreign policy and identify factors influencing foreign policy decisions.

The remainder of this article is as follows: (1) Next section is dedicated for literature review discussing the existing definition of foreign policy and overview of foreign policy studies, (2) The subsequent section outlines the research methodology and steps to conduct literature search, (3) Later, results and discussion were prepared, and (4) the final section presents the recommendations for future research and concluding remarks.

\section{Literature Review}

For more than 40 years, publications on foreign policy had emerged from defining the concept of foreign policy to the debates on democracy, foreign policy analysis, and to what extent foreign policy dictates international image (Carlsnaes, 1980; Caporaso, Hermann, Kegley, Rosenau, \& Zinnes, 1986; Zainol, Jusop, Ridzuan, \& Kamaruddin, 2019; Gusau, Abdulkadir, \& Musa, 2020; Efimova \& Strebkov, 2020). The following are interpretations of foreign policy definition according to several policy scholars.

\section{Definition Of Foreign Policy}

Frankel (1963) argued that the scope of foreign policy decision-making is boundless which according to him, it covers the whole universe. Besides, the author asserted that the decisionmaking of a country's foreign policy is not made by the country itself but by several individuals or groups of individuals representing the country. Generally, these individuals or groups of individuals are those who hold official positions rooted from the constitution, laws or legitimate systems.

In addition to Frankel (1963), there are some scholars who consider foreign policy as a sign of national action except such actions are mainly made for the phenomena that occur in the international arena. Coplin (1980) is among those who represent this agreement. According to him, foreign policy is a set of governmental actions directed to conditions outside borders (Coplin, 1980). Holsti (1992) agreed and came forward with the vision that foreign policy is a set of actions or ideas formed by policy makers (leadership or government) on what to do when it comes to international issues. To make it clearer, Holsti (1992) elaborated that foreign policy deals with political actions and viewed as an effort to find solutions to international problems that arise as a result of interaction between countries.

In another angle, Lenche and Samad (1963) shared similar perspective with Mas'oed (1990) who assumed that foreign policy is actually a form of response and reflection of contextual conditions either in international or domestic political affairs. Nevertheless, these authors stressed that foreign policy does not emphasized the action of political leaders or their 


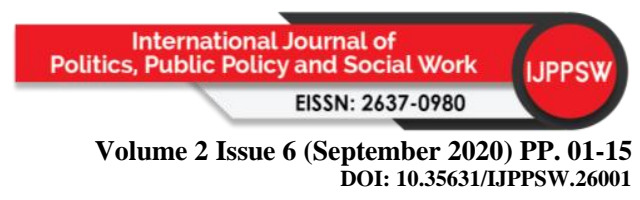

personal initiatives but only depends on certain circumstances that occur in other countries (Lenche \& Samad, 1963). In other words, response of a country (through international interaction) is heavily determined by the system among international countries (Mas'oed, 1990). The structure of that system and the changes it has made over the years will define the behaviour of international relations actors. Further, the existence of such systems among countries is conceived as contextual environments which attached to the policy and eventually determines the nation-state relationship.

On the same note, White (1989) offers a more robust definition of foreign policy which he had summarised the gist of foreign policy as: (i) government activities or (ii) the government itself which seeks to build good rapport between countries through political actors in the international system. This definition has clearly portrayed that foreign policy is a manifestation of 'friendship' among sovereign countries that bind laws and regulations that transcends borders but significantly rely upon political actors.

\section{Malaysian Studies On Foreign Policy - Premiership 1957-2020}

In brief, this section reviews the development of Malaysia's foreign policy from 1957 to 2020. After Malaysia gained independence in 1957, the foreign policy is divided into several phases. Researchers tend to classify these phases based on the Prime Minister's tenure. For instance, the era of Tunku Abdul Rahman (1957-1970); Tun Abdul Razak (1970-1976); Tun Hussein Onn (1976-1981); Tun Mahathir Mohamad (1981-2003); Tun Abdullah Ahmad Badawi (2003-2009), Datuk Seri Najib Razak (2009-2018), Tun Mahathir Mohamad (20182020), and Tan Sri Muhyiddin Yassin (2020 to present).

In the Tunku Abdul Rahman's era (1957-1970), foreign policy in Tanah Melayu or Malaya (now Malaysia) was to prioritise diplomatic ties with neighbouring countries since Malaya had just gained independence. At that time, the country was unstable due to the Communist threat while the military capabilities were at minimum (Omar, 2014). Not to mention the constant issues of mutual distrust and prejudices occurred among ethnics and inter-ethnic groups had divided the community in Malaya. This condition has provided Tunku with different challenges and problems compared to what the succeeding Prime Ministers went through. For that reason, the foreign policy within Tunku's era was quite low-key and subtle which Tunku put more efforts to sustain the newly independence nation, stabilise the country's political situation, strengthen military forces and more importantly, put more attention in reducing and narrowing the gap between ethnic groups in Malaya.

Looking at another viewpoint, foreign policy under the period of Tunku governance had stirring conflicts from the Southeast Asia (SEA) regions as a result of reaction or response to Tunku's efforts to form the Federation of Malaya (Malaysia). After the formation of Malaysia, the regional political situation also witnessed several events that challenged the country's diplomatic capability including the confrontation by Indonesia and the conflict with the Philippines related to their demands on Sabah. For that reason, Tunku was becoming more assertive to maintain his pro-Western principles in searching for international support and financial aids from the colonial powers (Saravanamuttu, 1972).

While struggling with the fragile state of people and a wide economic gap in Malaya, it was evident that Tunku tended to fight for the fate of Malays. In contrast, Lee Kuan Yew, the Prime Minister of Singapore had different opinions since he was more concern with the 


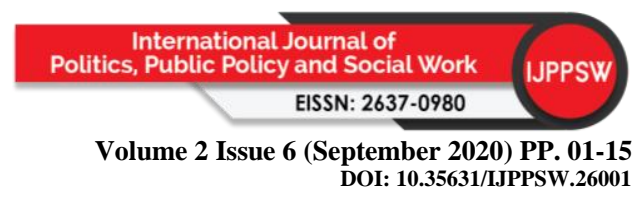

Chinese community. Starting from the incident, the clash of political stance between Tunku and Lee Kuan Yew had led to several international disputes which eventually made Singapore left after six years being part of the Federation of Malaya. Apart from the Communist threat, post-independence and nation-building situation; Tunku's decision to initiate and defy international relations had remarkably affect the structure of foreign policy in Malaysia to this day. Indeed, this past experience had proved that foreign policy during Tunku's era was reactive than proactive (Omar, 2014).

Next, the early stage of Tun Abdul Razak's premiership had witnessed the transition from pro-Western country to a more neutral, moderate and pragmatic (Omar, 2014). Tun Abdul Razak had pioneered efforts to make Malaysia's foreign policy more neutral by applying a policy that did not biased and established diplomatic relations with all countries except with certain countries without making ideology as in Tunku's time. The policy of neutrality not only applied in the domestic politics but also extended at the regional level through Association of Southeast Asian Nations (ASEAN). Later in 1971, ASEAN member states and the foreign ministers from Malaysia, Indonesia, Singapore, the Philippines, and Thailand had signed the Zone of Peace, Freedom and Neutrality (ZOPFAN). This declaration promotes international peace and security through law and regional cooperation. His decision on neutrality was motivated by the political turmoil in the regional and international arena. For instance, the involvement of United States government in Vietnam, China possession of nuclear power, the emergence of Japan as an international commerce hub, and the rise of Middle East/Muslim countries. These occurrences had calls for Tun Razak's interference in Malaysian foreign policy plans. He believed that Malaysia should be free from foreign countries dominance and avoid taking sides which explained his neutrality foreign policy to maintain harmonious relationship among foreign countries.

During the time of Tun Razak, the country had taken great steps to build regional resilience and enable ASEAN countries to become less dependent on external powers. Tun Razak also took a different path from Tunku by establishing diplomatic relations with the communist bloc countries such as Russia and China. Tun Razak firmly voiced out that Malaya is indeed a relatively small state yet; the government had to cope with many demands from internal and external sources. Among the internal issues include the effort to improve standard of living in Malaysia, provide basic amenities and social service which are necessary for an independent and civilised nation. On the other hand, the most crucial external issues were generally related to the defence and security concerns. Accordingly, Tun Razak decided to form collective security pacts with United Kingdom, Australia, and New Zealand (Saravanamuttu, 1972). Another remarkable Tun Razak's contribution was the enhanced bilateral cooperation with Singapore. At that time, there was no conflict arises between the two neighbouring countries (Omar, 2014).

Moving on to the next prime minister, Tun Hussein Onn; he did not show drastic changes in Malaysia's foreign policy. Certainly, he adhered to the neutrality policy which was a continuation from the previous Prime Ministers (Omar, 2014). Tun Hussein Onn was also seen to be more focused on relations with the countries within ASEAN. Looking from his insight, Tun Hussein was more concerned with the effort to strengthen existing diplomatic ties with neighbouring countries especially Singapore, Thailand and Indonesia. Leaders from these countries praised Tun Hussein Onn for his endeavour in making ASEAN functioning as 


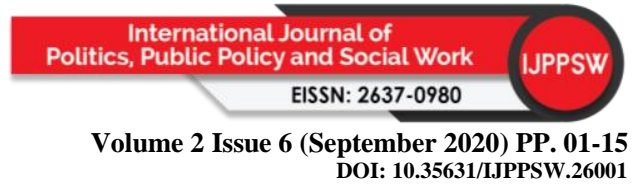

a successful vessel particularly in reinforcing good relationships among Southeast Asia countries (Jaafar, 2007).

Seven years after the racial riot in Malaya, Tun Mahathir Mohamad became the surprise choice of Tun Hussein Onn as his successor (Saravanamuttu, 1972). Since then, Tun Mahathir has been the longest-serving prime minister in Malaysia, which to be exact for 22 years. During his time, Malaysian foreign policy has been considered as independent, dynamic, and pragmatic (Khalid, 2009). Tun Mahathir is truly the one who brings the best in Malaysia and his visionary leadership had progressed Malaysia to be internationally recognised with relatively impressive economic growth (Saravanamuttu, 2008). Being labelled as a liberal Muslim, Tun Mahathir was evident to be very vocal about suppression of Muslim countries. Besides, he was one of the important figures in Organisation of the Islamic Cooperation (OIC) amid other Muslim world (Ministry of Foreign Affairs Malaysia, 2019).

There is undeniable that Malaysia had benefitted tremendously from the legacy of Tun Mahathir in fostering external relations with more nations while championing the rights, interests, and aspirations of Third World countries (Khalid, 2009). His strong personality and uncompromising stance had impacted the Malaysia's foreign policy orientation. Contrary to the previous prime ministers, Tun Mahathir opened up path for more diplomatic ties with the Northeast Asia countries such as Japan and South Korea (Saravanamuttu, 2008; Khalid, 2009). This action had carried numerous foreign policies targeted for economic development in Malaysia.

Political analysts affirmed Tun Mahathir's first strategy in foreign policy was to shift from political focus to the focus in accelerating economic growth (Khalid, 2009). Further, Tun Mahathir had expanded Malaysian foreign relations with Central Asia such as Kazakhstan and Uzbekistan. In brief, among foreign policies or external movements implemented during Tun Mahathir's era are Buy British Last, Look East Policy, Anti-British/AntiCommonwealth, defender of Third World countries, championing regional engagement, growing relations with Muslim world, and expansion of international cooperation from the Northeast Asia to Central Asia (Saravanamuttu, 2008; Khalid, 2009).

When Tun Abdullah Ahmad Badawi resumed the premiership from Tun Mahathir, he succeeded in his own way since Tun Abdullah's personality was totally different from Tun Mahathir. His soft character and accommodating style of leadership had been his strength and weakness all at once (Khalid, 2009). The legacy left by Tun Mahathir had worried Tun Abdullah to meet the standards of the flourishing foreign policy at that time. Nevertheless, Tun Abdullah managed to mark his distinctive contribution to foreign policy by successfully introduced the concept of moderate Islam or known as Islam Hadhari. With the mission towards excellence, glory, and distinction (cemerlang, gemilang, terbilang); this concept was recognised by the OIC member states in 2005 (Hamid, 2009). Thus, remarked his excellence in articulating foreign policies based on Islamic principles.

Despite the challenges Tun Abdullah facing within his political party - United Malays National Organization (UMNO) and the emerging opposition coalition; Islam Hadhari had attracted non-Muslim electorate and received positive response from the US. The US government acknowledged the moderate Islamic values in Islam Hadhari and praised Tun Abdullah's effort to shun radical mindset while portraying the positive philosophy of Islam 


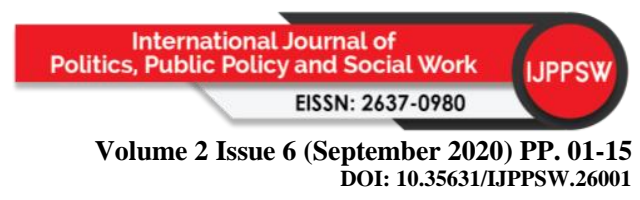

(Khalid, 2009). In addition, Tun Abdullah played an instrumental role in expanding the functions of OIC from political issues to the focus of socio-economic development of Islamic countries (Shafee, 2015). Within the economic spectrum, Tun Abdullah launched Halal industry which positioned Malaysia to be the leading Halal hub in wide range of competencies from accreditation to supply chain industry (Khalid, 2009). Tun Abdullah had successfully accentuated the image of Malaysia as progressive and moderate Islamic country to the international arena.

Later in the year 2009, Datuk Seri Najib Razak had succeeded Tun Abdullah as the sixth prime minister in Malaysia. During his tenure, Datuk Seri Najib had intensified foreign policies to cater with the changing world order. Among his prominent foreign policies are related to the restored bilateral relations with Singapore and China (Omar, 2014). His approach in developing foreign policy was deemed as forward-looking and pragmatic (Shafee, 2015). To emphasise the linkage between domestic and foreign policy, Datuk Seri Najib announced the concept - 1Malaysia: People First, Performance Now. This concept has been well-embodied with the main vision of Malaysian foreign policy without neglecting the challenging domestic agendas (Khalid, 2009).

Unexpectedly in 2018, for the first time ever (over sixty years), the Malaysian government was formed by a new political coalition (Moniruzzaman \& Farzana, 2018). The new coalition was named as Coalition of Hope (Pakatan Harapan). Tun Mahathir was announced as the prime minister for the second time at the age of 92 (Bernama, 2018). After 22 months, Tun Mahathir had abruptly resigned but appointed by the Yang di-Pertuan Agong as interim prime minister until the formation of a new government (Aziz, 2020). Throughout his administration, several foreign policies were taken place such as the condemnation of Myammar's treatment towards the Rohingya community at the 73th United Nations assembly (Bernama, 2020a) as well as reinforcing bilateral relations with Vietnam, Singapore, United States and China (Parameswaran, 2019).

Until recently (in 2020), Malaysia had witnessed the most remarkable shift of political turmoil after Tun Mahathir had resigned and became the interim prime minister. A week after agonizing moment for the fellow Malaysians, Tan Sri Muhyiddin Yassin was sworn as the eighth prime minister based on majority support from the member of parliament (Jaipragas, 2020). In total contrast with the previous premiership, Tan Sri Muhyiddin had to deal with completely different challenges. Despite the non-acceptance among public and political leaders, Tan Sri Muhyiddin had to deal with a much bigger predicament that is the prevalence of the Corona Virus Disease 2019 (COVID-19). It is imperative for the premiership helmed by Tan Sri Muhyiddin to eliminate racial and political conflict but to unite in combating the spread of COVID-19.

This pandemic had stunned the world in an unfavourable condition. Amid the COVID-19 issues, Tan Sri Muhyiddin efforts to deal with foreign policy should be praised. He expressed disagreement with China on the issue of South China Sea dispute and revoked several contracts for 5G services from Chinese corporations (Narang, 2020). These rejections prompted the political analyst to conclude that Malaysian government under the leadership of Tan Sri Muhyiddin had end the era of pro-China policies. On a brighter note, foreign policy machinery throughout Tan Sri Muhyiddin's tenure as at today (September 2020), still centred on bilateral cooperation with US and he remarked as bringing back the pro-Western 
approach. Referring to the official phone call from the US President, Donald Trump; both leaders expressed consensus on the importance of cooperation among international community to ease the impact of the pandemic to the well-being of people and the global economy (Bernama, 2020b).

Looking at the different approaches of foreign policy decisions undertook by each premiership, there are a number of factors involved. Indeed, there is a consensus among policy researchers that foreign policy decisions entail multi-facet of contributing factors from personal interest, personality disposition, official position, societal pressure, among others (Dugis, 2007; Ozdemir \& Serin, 2016; As, 2018). With that, more research should be done to unearth the factors of foreign policy decisions to equip policy makers on what to expect when formulating an efficient foreign policy.

\section{Methodology}

This study employs secondary data which derived from past publications and literature review with respect to foreign policy topics. The analysis of literature review was extracted from reputable databases by using these keywords: Foreign policy, foreign policy decisions, international affairs, and international relations. The selection of foreign policy articles is not limited to Malaysian foreign policy but also inclusive of international foreign policies. The literature search was limited to English sources, published in Scopus and ScienceDirect as well as indexed in Google Scholar from 1960 to 2020.

\section{Results and Discussion}

Working on the scarcity of detailed definition of foreign policy, this study had compiled a list of established definition as reference. From there, the definitions were synthesis for similar meanings and detached from external variables. A compilation of foreign policy definitions was summarised in Table 1.

Table 1: Compilation of Foreign Policy Definition

\begin{tabular}{ll}
\hline \multicolumn{1}{c}{ Author } & Definition - Foreign Policy (FP) \\
\hline Frankel (1963) & $\begin{array}{l}\text { Government decisions and actions through official and } \\
\text { non-official documents and speeches. }\end{array}$ \\
Hoffman (1968) & $\begin{array}{l}\text { Foreign policy in the simplest form is considered as } \\
\text { politics in the international scene. }\end{array}$ \\
Rosenau (1984) & $\begin{array}{l}\text { Authoritative actions taken by governments or their } \\
\text { commitment to give order either to maintain the desirable } \\
\text { aspects of the international environment or to amend its }\end{array}$ \\
undesirable aspects. & $\begin{array}{l}\text { A program either in terms of goal-oriented or problem- } \\
\text { oriented program, being formulated by policymakers and } \\
\text { directed towards entities outside the state's political }\end{array}$ \\
jurisdiction. & $\begin{array}{l}\text { Purposeful action in fulfilling national interest stemming } \\
\text { from political-level decision based on individual or } \\
\text { groups consideration. }\end{array}$
\end{tabular}

Source: Frankel (1963), Carlsnaes (1980), Rosenau (1984), Hermann (1990), As (2018) 


\section{Definition - Foreign Policy}

Most often, existing researchers defined foreign policy as too narrow and inclusive of several specific variables to fit with their research objective (in a particular study). Working upon this discrepancy, this study presented a basic and detailed definition of foreign policy as follows:

- Basic definition: Foreign policy is interpreted as the decision or action of a country when dealing with the outside world whether from sovereign countries, government or non-governmental organizations (such as United Nations, NATO, ASEAN, etc.).

- Detailed definition: In the context of Malaysia's foreign policy, foreign policy can be either a decision or action taken by the Malaysian government or its representatives whenever they are dealing with international states or organizations with the efforts to envision national aspirations in the global political arena.

\section{Factors influencing foreign policy decisions}

Several themes emerged from the literature search in analysing factors influencing foreign policy decisions and the themes were divided into five groups namely; individual, role, government, society, and system (see Table 2).

Table 2: Factors Influencing Foreign Policy Decisions

\begin{tabular}{ll}
\hline Factor & Description \\
\hline Individual & - The personality of the leader of a country. \\
Role/Position & - Behaviour of officers involved in processing foreign policy \\
Government & - Structures that either limit or expand foreign policy alternatives \\
Society & - Non-governmental aspects such as the people or occupants whose \\
& $\begin{array}{l}\text { conditions affect or contribute to the filling of a country's foreign } \\
\text { policy }\end{array}$ \\
System/ & - The external environment of a country \\
External &
\end{tabular}

Source: Rosenau (1966)

There are numerous factors that influence the decision-making in foreign policy. Most often, previous literature argued that the pattern of foreign policy structure corresponds closely to the idiosyncratic factors of top-level policy makers. By definition, idiosyncratic factors refer to the politicians' beliefs, personality traits, psychological dispositions, and individual preferences (Saravanamuttu, 1972; As, 2018). In a different outlook, some group of policy analysts sided with Rosenau's (1966) pre-theory and believed there are other variables such as role, government, society, and system as inputs for foreign policy decision-making.

\section{Individual}

Among other factors, psychologists and political scientists continuously pull together different strands of research on how individual-level ideologies possibly shape the international attitudes and influence the foreign policy preferences (Gries \& Yam, 2020). In essence, the individual factor is related to the outlook on life, beliefs, and stance or individual idiosyncrasies that determine a country's foreign policy. These factors also refer to the perceptions, image and personal character of the individual who decide the foreign policy decisions of a country. The personality of the individuals, who are typically the policy 


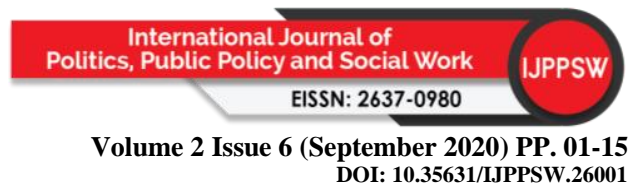

makers, may consider one of these alternatives: calmness or urgency, anger or caution, pragmatism or ideology (eradication), superiority or backwardness, creativity or destruction, fear or excessive self-confidence, among others (Jaafar, 2007). In another outlook, individual factors also comprise of past experiences, values, political and leadership styles that create uniqueness and had empirically improved the quality of foreign policy decisions.

In fact, it is undeniable that the behaviour and state-leader's preference, as well as other political inclination have a certain influence on the foreign political outcomes. However, it must be acknowledged that the specific source associated with one's character is very difficult to measure (Rosenau, 1966). For instance, there are some elements that historically influenced the past leaders' foreign policy decisions such as their marital status (Hitler Germany), type and quality of education (Mandela - Africa), family background (Bush -US), social background (Obama - US), royal influence (Tunku - Malaysia), financial position (Trump - US), among others.

\section{Role/Position}

Role factor is usually defined as job descriptions or rules of conduct expected for a person holding a particular position. Among the role or some researchers referred as the position includes: Prime Minister, Cabinet Ministers, High Officers, Representatives of Congress and Senators, journalists, educators, workers' associations, and the leaders of opposition groups. These groups of people are regarded as elites who influence, formulate, and implement the foreign policy of a country (Efimova \& Strebkov, 2020). These officers carry a set of responsibilities and assigned to undertake certain tasks, which in turn form a kind of interaction among them. This factor (role) is detached from a person's psychological profile when he or she holds a specific position.

Role factors are also more appropriate to be used in explaining pragmatic and tactical decisions in a competitive democratic society. It was evident that pragmatic decisions require a lot of time and input in the decision-making process (Omar, 2014). Unlike for crisis decisions, the leader is compelled to act impulsively but with caution. Not many parties involve in the foreign policy decisions specifically for situation of pandemic, financial crises, and catastrophe (Gries \& Yam, 2020). Role factors are also more appropriate in a democracycompetitive system because the behaviour of decision-makers is clearly visible and open to criticism. One thing for sure is the results of decision-making of foreign policy are tailored to the public's expectations of the position held by an individual. Without the role/position, the person probably deviates and makes a different kind of policy decision. Therefore, foreign policy researchers should clearly distinguish the difference between individual and role factors. Similarly, both factors influence the structure of foreign policy machinery in global politics (As, 2018).

\section{Government}

Government factors refer to the forms of government institutions (authoritarian vs. democratic), the distribution of influence among the institutions, the procedures to select and recruit government servants, the interests that the institutions are representing, and the extent to which these institutions are open to societal influences (Efimova \& Strebkov, 2020). In other words, it is related to the structure and process of governance and its impact on the foreign policy of a particular country. These factors include the organizational structure of government, the decision-making process at various stages of policy cycle, the various 


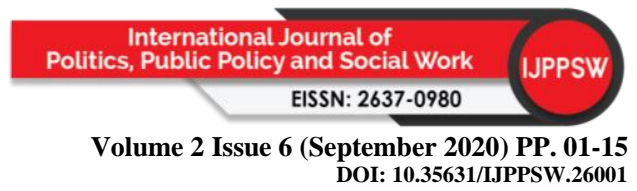

techniques for implementing political decisions, and the attitude of officers who are related to the impact of foreign policy on domestic politics, public welfare, and the general well-being of the country.

To illustrate the example on how a government, shape the foreign policy decisions, this paper put forward North Korea and Malaysian government. Foreign policy in North Korea can be viewed as closed system and decision-making process is easier and faster to be made as compared to Malaysian foreign policy (As, 2018). Multiple layers of parliamentary debates and various inputs from mass consultation seize a longer time for Malaysian foreign policy decisions to be approved. More broadly, these illustrations depicted that both countries opted for different foreign policy approach which North Korea prefer to act as the sole decisionmaker without the need to refer or depend on other countries. In contrast, any foreign policy in Malaysia is made based on diplomatic ties with other countries. The North Korea government decided to work in isolation and shun international relations, while Malaysia treasure the good terms of global cooperation.

\section{Society}

Society or societal factors are related to the national character or national elements of a country (Dugis, 2007). These factors include contextual variables such as the area of a country, type of region, geographical location, climate and natural resources of the country. Hopkins and Mansbach (1973) asserted that societal factors also include nongovernmental aspects of a society such as political culture, economic capability, social cohesion, and basic values. For a different view, Barkdull and Harris (2002) suggested that societal factors impacted foreign policy based on the domestic politics in a country itself together with its particular local culture. In particular, this factor also scrutinizes a country's population, gross domestic product (GDP), as well as the economic, political, and social system of a country.

As such, observing Malaysian GDP as a reference, political leaders in Malaysia turned to developed countries such as US, Japan, and European countries (among others) for international cooperation with the aim to improve the national economic performance. Another example is regarding the climate and natural resources in Malaysia. Since Malaysia is a tropical country, the government should look for similar conditions and most often, Malaysia consults and negotiates with Thailand and Australia for agriculture programmes.

\section{System/External}

If the social factor is related to the national elements of a country, the system or also known as external factor is the opposite. System refers to the external variable of a country and includes the policies and actions of other countries that will stimulate a country's political response (Couloumbis \& Wolfe, 1990; Dugis, 2007; Siniver \& Featherstone 2020). For example, the Cold War bipolar system forcing a country to choose sides and compelled to cooperate with certain countries during the Cold War era. Other than that, the existence of multi-polar system marked the emergence of Non-Aligned Movement (NAM). Non-Aligned Movement (NAM) is a group of countries that refuse to ally politically and militarily with the Western bloc as well as the Eastern bloc (Jaafar, 2007).

The movement began with the events of the Asia-Africa Conference in 1955 and NAM declared itself as the third force in the world political system. As these two systems (post- 


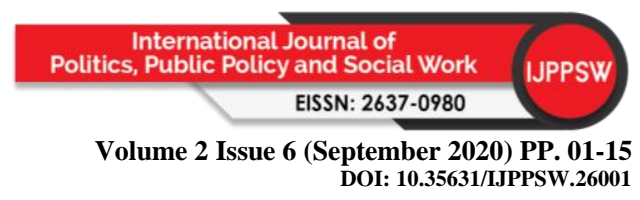

Cold war which divided the entire world and impartial NAM countries) took place, the entire international system and foreign policy are also changed (Jaafar, 2007). Motivating from Gries and Yam's (2020) work on ideology and international relations, this factor (system) is evidently the primary factor that being translated into foreign policy around the globe. A good example to present this idea can be observed from the issue of COVID-19. China's policy of lockdown (in Wuhan) had pressure other countries to react and decide whether to replicate or counter with opposite policy. Another illustration offered by Gries and Yam (2020) showed how military power in a country could lead towards the world war or peace, which provoke other country to formulate responsive foreign policy as a reaction.

\section{Conclusion}

Despite all efforts taken by political scientists to elucidate the definition of foreign policy, there is still a lot of work to do towards a mutually exclusive understanding of fundamentals of foreign policy. Indeed, a number of challenges have continued to strike Malaysian government in formulating and responding to international issues. Definition of foreign policy constantly focused on international relationships among countries and the pivotal role of government in executing foreign policy. However, attention should be drawn upon the importance of contextual elements such as the functions of policy actors based on their roles or positions in the office along with their personal characters. All in all, the implication of non-governmental aspects and political culture through society and system are equally important to formulate an effective foreign policy. It is advisable for the government to adapt and respond attentively to the changes surrounding the nation by practicing fair diplomacy in the current interdependent globalized world.

\section{References}

As, B. (2018). The study of foreign policy in international relations. Journal of Political Sciences \& Public Affairs, 6(4), 1-9. doi: 10.4172/2332-0761.1000337.

Aziz, A. (2020, February). PMO confirms Dr M's resignation. The Edge Markets. Retrieved September 1, 2020 from https://www.theedgemarkets.com/article/dr-m-said-resignpmo-issue-statement.

Barkdull, J., \& Harris, P. G. (2002). Environmental Change and Foreign Policy: A Survey of Theory. Global Environmental Politics, (2)2, 63-91. doi: $10.1162 / 15263800260047835$.

Bernama. (2018, May). Mahathir returns, sworn in as 7th PM. Malaysiakini. Retrieved September 1, 2020 from https://www.malaysiakini.com/news/424173.

Bernama. (2020a). Mahathir's surprises as PM4, PM7 and PM7+. Free Malaysia Today. $\begin{array}{llll}\text { Retrieved September } & 1, & 2020 & \text { from }\end{array}$ https://www.freemalaysiatoday.com/category/nation/2020/02/24/mahathirs-surprisesas-pm4-pm7-and-pm8/.

Bernama. (2020b). Bilateral cooperation, COVID-19 among topics discussed between PM Muhyiddin and Trump. Prime Minister's Office of Malaysia. Retrieved September 1, 2020 from https://www.pmo.gov.my/2020/05/bilateral-cooperation-covid-19-amongtopics-discussed-between-pm-muhyiddin-and-trump/.

Bevir, M., \& Daddow, O. (2015). Interpreting foreign policy: National, comparative and regional studies. International Relations, 29(3), 273-287.

Caporaso, J. A., Hermann, C. F., Kegley, C. W., Rosenau, J. N., \& Zinnes, D. A. (1986). The Comparative Study of Foreign Policy: Perspectives on the Future. Paper presented at 


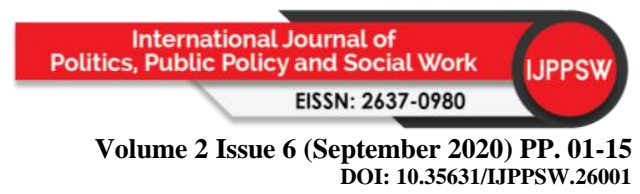

the Annual Meeting of the International Studies Association (25-29 March 1986). Retrieved September 2, 2020 from https://files.eric.ed.gov/fulltext/ED271365.pdf.

Carlsnaes, W. (1980). The concept of foreign policy actions in comparative analysis. Cooperation and Conflict, 15(1), 3-20. doi: 10.1177/001083678001500102.

Couloumbis, T. A., \& Wolfe, J. H. (1990). Pengantar Hubungan Internasional: Keadilan dan Power. Bandung, Indonesia: Abardin.

Coplin, W. D. (1980). International Politics: An Introduction, New Jersey: Prentice Hall.

Dugis, V. (2007). Analysing Foreign Policy. Masyarakat, Kebudayaan dan Politik, 20(2), 113-124.

Efimova, A., \& Strebkov, D. (2020). Linking Public Opinion and Foreign Policy in Russia. The International Spectator, 55(1), 93-111. doi: 10.1080/03932729.2019.1700040.

Erdogan, A., \& Habash, L. (2020). US Policy Toward the Israeli-Palestinian Conflict under the Trump Administration: Continuity or Change?. Insight Turkey, 22(1), 125-146. doi: 10.25253/99.2020221.09.

Frankel, J. (1963). The Making of Foreign Policy. London, UK: Oxford University Press.

Gries, P., \& Yam, P. P. C. (2020). Ideology and international relations. Current Opinion in Behavioral Sciences, 34, 135-141. doi: 10.1016/j.cobeha.2020.03.006

Gusau, A. S., Abdulkadir, S., \& Musa, M. B. (2020). Traditional governance system and the control of insurgency in Bade Emirate, Yobe State. International Journal of Politics, Public Policy and Social Works, 2(4), 17-28. doi: 10.35631/IJPPSW.24002.

Haesebrouck, T., \& Joly, J. (2020). Foreign Policy Change: From Policy Adjustments to Fundamental Reorientations. Political Studies Review, 1-10. doi: 10.1177/1478929920918783.

Hamid, A. F. A. (2009). The new challenges of political Islam in Malaysia. In Asia Research Centre Conference on 'New Modes of Governance and Security Challenges in the Asia-Pacific', Murdoch University, Perth. Retrieved September 1, 2020 from https://www.academia.edu/331967/.

Hara, A. E. (2012). Re-engagement in American Foreign Policy toward Southeast Asia: Some Responses and Perspectives from Indonesians. Southeast Asian Journal of Social and Political Issues, 1(2), 117-131.

Hermann, C. F. (1990). Changing course: when governments choose to redirect foreign policy. International Studies Quarterly, 34(1), 3-21. doi: 10.2307/2600403.

Holsti, K. J. (1992). Politik Antarabangsa: Satu Rangka Kerja Analisis (terjemahan), Kuala Lumpur: Dewan Bahasa dan Pustaka.

Hopkins, R. F., \& Mansback, R. W. (1973). Structure and Process in International Politics. New York: Harper \& Row.

Jaafar, F. (2007). Perdana Menteri dan Dasar Luar Malaysia 1957-2005, Kuala Lumpur: Universiti Malaya.

Jaipragas, B. (March, 2020). How Malaysia got its eighth Prime Minister Muhyiddin Yassin. South China Morning Post. Retrieved September 1, 2020 from https://www.scmp.com/week-asia/politics/article/3053062/how-malaysia-got-itseighth-prime-minister-muhyiddin-yassin.

Kattan, V. (2020). Israeli Settlements, US Foreign Policy, and International Law. Insight Turkey, 22(1), 47-57. doi: 10.25253/99.2020221.04.

Khalid, K. M. (2009). Malaysian foreign policy orientation and relations in the PostMahathir years (Doctoral dissertation, Universiti Malaya). Retrieved from 
http://eprints.um.edu.my/10906/1/11_Malaysian_Foreign_Policy_Orientation_and_

Relations_in_the_Post-Mahathir_Years.pdf.

Lacatus, C., \& Meibauer, G. (2020). Introduction to the special issue: Elections, rhetoric and American foreign policy in the age of Donald Trump. Politics, 1-12. doi $0.1177 / 0263395720935376$.

Lenche, C. O., \& Samad, A. A. (1963). Concept of International Politics, London: Princeton Hall Inc. Englewood Chiffs.

Mas'oed, M. (1990). Ilmu Hubungan Internasional-Disiplin dan Metodologi, Jakarta: LP3ES Publisher.

Ministry of Foreign Affairs Malaysia. (2019). Foreign policy framework of the new Malaysia: Change in Continuity. Department of Information Malaysia. Retrieved September 1, 2020 from https://www.kln.gov.my/foreign-policyframework/files/assets/common/downloads/Foreign\%20Policy\%20Framework.pdf.

Moniruzzaman, M., \& Farzana, K. F. (2018). Malaysia'14th General Election: End of an epoch, and beginning of a new?. Intellectual Discourse, 26(1), 207-228.

Narang, A. (2020, August). With Muhyiddin Yassin at the helm of affairs in Malaysia, China has a new enemy in Southeast Asia. TFI Post. Retrieved September 1, 2020 from https://tfipost.com/2020/08/with-muhyiddin-yassin-at-the-helm-of-affairs-inmalaysia-china-has-a-new-enemy-in-southeast-asia/.

Omar, R. (2014). An analysis of the underlying factors that affected Malaysia-Singapore relations during the Mahathir era: Discords and continuity (Doctoral dissertation, University of Adelaide). Retrieved September 1, 2020 from https://digital.library.adelaide.edu.au/dspace/bitstream/2440/86749/8/02whole.pdf.

Ozdemir, E., \& Serin, Z. V. (2016). Trading state and reflections of foreign policy: Evidence from Turkish foreign policy. Procedia Economics and Finance, 38, 468-475. doi: 10.1016/S2212-5671(16)30218-0.

Parameswaran, P. (2020, May). Malaysia's new foreign policy framework: Between change and continuity. The Diplomat. Retrieved September 1, 2020 from https://thediplomat.com/2019/05/malaysias-new-foreign-policy-framework-betweenchange-and-continuity/.

Rosenau, J. N. (1966). Pre-theories and theories of foreign policy. In Farrell, R. B. (Ed.). Approaches to comparative and international politics. Evanston, USA: Northwestern University Press.

Rosenau, J. N. (1984). A pre-theory revisited: World politics in an era of cascading interdependence. International Studies Quarterly, 28(3), 245-305. doi: $10.2307 / 2600632$.

Saravanamuttu, J. (1972). A study of the content, sources, and development of Malaysian Foreign Policy 1957-1975. (Doctoral dissertation, University of British Colombia). Retrieved from https://open.library.ubc.ca/collections/831/831/items/1.0093814.

Saravanamuttu, J. (2008). Malaysia's Foreign Policy in the Mahathir Period, 1981-1995: An Iconoclast Come to Rule. Asian Journal of Political Science, 4(1), 1-16. doi: $10.1080 / 02185379608434069$.

Shafee, M. S. (2015). Malaysia's foreign policy. Retrieved September 1, 2020 from https://www.slideshare.net/muhammadsyukhrishafee/malaysias-foreign-policy.

Siniver, A., \& Featherstone, C. (2020). Low-conceptual complexity and Trump's foreign policy. Global Affairs, 6(1), 71-85. doi: 10.1080/23340460.2020.1734953. 
Sundstrom, M. S., \& Elgstrom, O. (2019). Praise or critique? Sweden's feminist foreign policy in the eyes of its fellow EU members. European Politics and Society, 21(4), 418-433. doi: 10.1080/23745118.2019.1661940.

White, B. (1989). Analysing Foreign Policy: Problems and Approaches dalam Michael Clarke and Brian White, Understanding Foreign Policy, The Foreign Policy Systems Approach, England: Edward Elgar Publishing Limited.

Zainol, N. A. M., Jusop, A. Z., Ridzuan, A. A., \& Kamaruddin, S. (2019). Managing Malaysian border: The challenges and prospects in maintaining security International Journal of Politics, Public Policy and Social Works, 1(3), 1-13. doi: 10.35631/ijppsw.13001. 